\title{
Survey of Vesicular-Arbuscular Mycorrhizal Fungi in the Faculty of Agriculture Farm, Al-Azhar University, Assiut Governorate Said Abbas Mohammed El-Sayed ${ }^{1}$
}

\begin{abstract}
The growth and yield response of a greenhouse experiments were conducted to investigate soybean plants to colonization by 20 isolates (including G. glomus and 3 Gigaspora species) of vesicular-arbuscular mycorrhizal fungi. Each isolate was evaluated in a high $\left(71 \mathrm{~kg} /\right.$ fed. Bray-1 $\left.\mathrm{P}_{2} \mathrm{O}_{5}\right)$ and a low $\left(21 \mathrm{~kg} / \mathrm{fed}\right.$. Bray- $\left.1 \mathrm{P}_{2} \mathrm{O}_{5}\right)$ fertility soil. Colonization by most Glomus isolates significantly increased plant top dry weight and seed yields. These isolates produced a high increases in dry weigh in the low of soil fertility . Colonization by five of the Gigaspora isolates did not significantly affect top dry weight and seed yield in the high or low fertility soil. The value of comparative testing of species is discussed.
\end{abstract}

Key words: Glomus sp., Gigaspora sp., Glycine max, vesicular-arbuscular (VA) mycorrhizal fungi.

\section{INTRODUCTION}

It is well established that soybean (Glycine max L. Meer.) is one of many species of plants that can respond in positive manner to colonization by vesiculararbuscular (VA) mycorrhizal fungi (Gerdemann, 1968 and Mosse, 1973). Significant increases in growth and yield of soybean have been documented under a variety of experimental conditions (Ross and Harper,1970; Ross,1971; Schenck and Hinson, 1973) and although significant increases in yield have yet to be convincingly demonstrated under field conditions, it has been suggested that VA mycorrhizal fungi may contribute to the maximizing of soybean yields, in the field (Ross and Harper, 1970).

A recent reorganization of the family Endogonaceae classifies genera and species of fungi capable of participating in VA mycorrhizal associations (Gerdemann and Trappe, 1974). Of these species, many are frequently found in agricultural soils used for soybean production. Because many, if not all, species of VA mycorrhizal fungi found in agricultural soils may be capable of synthesizing VA mycorrhizae with soybean, it is relevant to determine the relative responses of soybean plants to isolates of various species of VA mycorrhizal fungi, then the more effective isolates may be selected for intensive examination under field conditions. In this greenhouse study, the 20 isolates of VA mycorrhizal fungi, will be evaluated and comparing their relative influence on soybean growth and yield.

\section{MATERIALS AND METHODS}

Two experiments were conducted. In experiment 1 , 13 isolates, including five species, of the genus Glomus were tested. With the exception of Glomus etunicatus (Becker and Gerdemann,1977), all species of experiment 1 were identified on the basis of descriptions given by Gerdemann and Trappe (1974). These isolates were obtained form a variety of geographic and ecological environments, then each was maintained in pot culture with soybean for more than 2 years prior to this experiment. The experiment 1 fungi are summarized in Table (1). Experiment 1 was run concurrently with experiment 2 . In experiment 2 , seven isolates, including three species of Gigaspora (Gerdemann and Trappe,1974 ; Becker and Hall, 1976) and one species of Glomus (Daniels and Trappe, 1979) were tested. The inoculum for all but one (Gigaspora margarita no. 3) of these seven isolates had been produced in other laboratories. Because of differences in the growth media (soil mixtures, fertility, etc.) in which the experiment 2 inocula had been produced, it was necessary to establish a control for each of the seven isolates. Additional information about the experiment 2 isolates is summarized in Table (2).

All fungi were tested in a low and a high fertility soil mixture which was prepared by blending three parts sand with one part high or low fertility clay loam soil. After blending, the soils were sterilized with Dowfume Mc.2 ,applied at the approximate rate 2 $\mathrm{kg} / 1,000 \mathrm{~kg}$ soil. The low fertility soil contained the noted concentrations of the following elements: Bray-1 $\mathrm{P}_{2} \mathrm{O}_{5}-21 \mathrm{~kg} /$ fed., Bray - $2 \mathrm{P}_{2} \mathrm{O}_{5}-47 \mathrm{~kg} /$ fed., $\mathrm{Ca}-386$ $\mathrm{kg} / \mathrm{fed}$., Mg-48 kg/fed., and $\mathrm{K}-30 \mathrm{~kg} / \mathrm{fed}$. In the high fertility soil the concentrations were Bray-1 $\mathrm{P}_{2} \mathrm{O}_{5}-71$ $\mathrm{kg} /$ fed., Bray-2 $\mathrm{P}_{2} \mathrm{O}_{5}-135 \mathrm{~kg} / \mathrm{fed}$., Ca-852 kg/fed., Mg$108 \mathrm{~kg} / \mathrm{fed}$., and $\mathrm{K}-83 \mathrm{~kg} / \mathrm{fed}$.

Twenty-centimeter clay pots were filled as high with the low or high fertility soil mixture and fungal inocula (inocula are described in detail in Table 1 and 2) were blended into the central third of the soil mixture. Five grams of Rhizobium japonicum (Kirchner)Buchanan (strains 5708, 5706, 5708-6,

${ }^{1}$ Soil and Water Sci. Dept., Faculty of Agriculture in Assiut, 
Table 1. Summary of experiment 1 fungi

\begin{tabular}{lcc}
\hline Treatment & Geographic source & Number of spores $^{\dagger}$ \\
\hline Control (non-mycorrhizal) & Belgium & 1000 \\
\hline Glomus mosseae No. 2 & Egypt & 1200 \\
\hline Glomus mosseae No. 1 & Egypt & 400 \\
\hline Glomus microcarpus No. 5 & Belgium & 500 \\
\hline Glomus microcarpus No. 4 & Egypt & 600 \\
\hline Glomus microcarpus No. 3 & Sweden & 700 \\
\hline Glomus microcarpus No. 2 & Egypt & 2000 \\
\hline Glomus microcarpus No. 1 & Egypt & 1000 \\
\hline Glomus fasciculatus N. 2 & Canada & 400 \\
\hline Glomus fasciculatus N. 1 & The Netherlands & 800 \\
\hline Glomus etunicatus & Sweden & 800 \\
\hline Glomus caledonius no. 2 & Egypt & $-*^{*}$ \\
\hline Glomus caldeonius no. 1 & - & \\
\hline
\end{tabular}

$\dagger \quad$ The inoculum of each fungus consisted of soil - root - fungus mixture.

Each pot received $200 \mathrm{~g}$ of the appropriate inocuum. The numbers listed indicate the approximate number of chlamydospores present in the respective 200 -g samples. Since spores may represent only a fraction of the infective propagules in each aliquot of mixed inoculum, the numbers cannot be interpreted as a reflection of the total number of infective propagules.

+ Each control pot received a twice autoclaved 200-g aliquot of G. fasciculatus no. 1 inoculum, plus nonsterile G. fasciculatus no. 1 culture filtrates.

Table 2. Summary of experiment 2 fungi

\begin{tabular}{lclcc}
\hline \multirow{2}{*}{ Fungus } & $\begin{array}{c}\text { Geo-graphic } \\
\text { source }\end{array}$ & Previous host & \multicolumn{2}{c}{ Mycorrhizal inoculum $^{\text {Quantity }^{\dagger}}$} \\
\hline Glomus epigaeus & France & Araucarice excelsa R.Br. & Spores $^{\ddagger}$ & 800 \\
\hline Gigaspora coralloidea & Egypt & Glycine max L. Merr. & 100 & 300 \\
\hline Gigaspora gigantean & USA & Glycine max L. Merr. & 10 & 50 \\
\hline Gigaspora margarita no. 4 & USA & Glycine max L. Merr. & 10 & 125 \\
\hline Gigaspora margarita no. 3 & Egypt & Glycine max L. Merr. & 100 & 250 \\
\hline Gigaspora margarita no. 2 & Sweden & Srghum vulgare pers. & 100 & 500 \\
\hline Gigaspora margarita no. 1 & Egypt & Medicago sativa L. & 100 & 700 \\
\hline
\end{tabular}

$\dagger$ Inoculum of each Gigaspora species consisted of a soil-root-fungus mixtures. Numbers listed indicate the quantity in grams, added to each pot in the respective treatments. Control pots received identical amounts of twice autoclaved inoculum, plus nonsterile filtrates form the appropriate inoculum.

$\$$ Indicates the approximate number of spores present in each aliquot of the mixed inoculum. Since spores may represent only a fraction of the infective propagules in the aliquot of mixed inoculum, (with the exception of G. epigaeus where inoculum consisted of spores only) the numbers cannot be interpreted as a reflection of the total number of infective propagules.

$\S$ Inoculum consisted of spores only. Controls received equivalent amount of heat killed spores, plus nonsterile filtrates from G. epigaeus spores.

Research Seeds. Inc., St. Joseph, Mo.) were blended into the top $3 \mathrm{~cm}$ of soil. Treatments in experiment 1 were replicated eight times; those in experiment 2 three times.

Five soybean seeds, cv. (Giza 82) were planted and thinned in the greenhouse under 14 hours of daylight supplemented by fluorescent incandescent lighting. Temperatures ranged from $28-32^{\circ} \mathrm{C}$ in the daytime to $16-20^{\circ} \mathrm{C}$ at night. Plants were watered as needed with deionized water and were harvested 17 weeks after planting. Root, top, and seed samples were oven-dried at $50^{\circ} \mathrm{C}$ to a constant weight. A $100-\mathrm{g}$ sample of soil from each pot of each treatment was wet sieved at the conclusion of the experiments. The sievings were scanned under a binocular microscope to confirm the presence of spores of the appropriate fungus.

\section{RESULTS AND DISCUSSIONS}

Spores and extramatrical mycelium were recovered by wet sieving from pots of each mycorrhizal treatment at the conclusion of the experiments. This verified the viability of the original inocula and also confirmed the fact that mycorrhizae had been synthesized in each treatment. Neither extramatrical mycelium nor spores were recovered from the non-mycorrhizal control pots. 


\section{Experiment 1}

The magnitude of difference in growth and yield between mycorrhizal and non-mycorrhizal (control plants is best illustrated by the differences in top dry weight (TDW) in the low fertility soil (Table 3), where colonization by each of the 12 isolates resulted in significant increases over the control. In the high fertility soil (Table 3), the difference in TDW between mycorrhizal and control plants was not as great, through 7 to the 12 isolates did not produce significant increases.

Increases in the number of pods $(\mathrm{P})$, number of seeds (S) and in seed dry weight (SDW) were also observed in mycorrhizal plants grown in either the low or high fertility soil. Significant $(\mathrm{P}<0.05)$ increases in each of these three parameters were produced by 11 of the 12 isolates in the low fertility soil, and by 8 of the 12 isolates in the high fertility soil (Table 3 ).

Of the 12 isolates tested, $\mathrm{G}$, mosseae no. 1 emerged as superior by inducing the largest growth and yield increases in the high and low fertility soil mixtures. Two other isolates, $\mathrm{G}$, fasciculatus no. 1 and $\mathrm{G}$. microcarpus no. 1, performed nearly as well as G. mosseae no. 1 and were also found in the top statistical category in the high and low fertility groups. Three other isolates, G. fasciculatus no. 2, and G. microcarpus no. 4 and 5, were considerably less effective in both soils, although all were significantly larger than the control in the low fertility soil.

Table 3. Growth and yield responses of soybean to colonization by the experiment 1 fungi in a high or low fertility soil

\begin{tabular}{|c|c|c|c|c|c|}
\hline Treatment $^{\dagger}$ & $\begin{array}{l}\text { Top dry } \\
\text { weight }\end{array}$ & $\begin{array}{c}\text { Root dry } \\
\text { weight }\end{array}$ & No. pods ${ }^{\ddagger}$ & No. seeds ${ }^{\ddagger}$ & $\begin{array}{c}\text { Seed dry } \\
\text { weight }\end{array}$ \\
\hline \multicolumn{6}{|c|}{ Low fertility } \\
\hline Control (non-mycorrhizal) & $3.3^{1}$ & $2.6^{\mathrm{gh}}$ & $5.0^{\mathrm{k}}$ & $5.4^{1}$ & $1.0^{1}$ \\
\hline Glomus fasiculatus N. 2 & $5.2^{\mathrm{k}}$ & $3.5^{\mathrm{ch}}$ & $7.8^{j}$ & $13.5^{\mathrm{hi}}$ & $1.6^{\mathrm{kI}}$ \\
\hline Glomus microcarpus No. 5 & $5.5^{\mathrm{jk}}$ & $4.5^{b f}$ & $8.6^{\text {hij }}$ & $15.5^{h}$ & $1.9^{\mathrm{ijk}}$ \\
\hline Glomus microcarpus No. 4 & $5.8^{\mathrm{jk}}$ & $2.9^{\mathrm{fgh}}$ & $8.0^{\mathrm{ij}}$ & $16.5^{\text {fgh }}$ & $1.9^{\mathrm{ijk}}$ \\
\hline Glomus caledonius no. 2 & $5.9^{\mathrm{hk}}$ & $2.2^{\mathrm{h}}$ & $9.3^{\mathrm{gj}}$ & $16.9^{\mathrm{fgh}}$ & $1.9^{\mathrm{ijk}}$ \\
\hline Glomus faciculatus N. 1 & $7.1^{\mathrm{g} j}$ & $3.7^{\mathrm{ch}}$ & $10.8^{\mathrm{fj}}$ & $20.1^{\text {efg }}$ & $2.4^{\text {hij }}$ \\
\hline Glomus microcarpus No. 3 & $7.2^{\mathrm{gj}}$ & $3.6^{\mathrm{ch}}$ & $12.4^{\mathrm{cg}}$ & $22.9^{\mathrm{de}}$ & $2.8^{\text {fgh }}$ \\
\hline Glomus microcarpus No. 2 & $7.3^{\mathrm{fi}}$ & $3.3^{\mathrm{dh}}$ & $11.0^{\mathrm{fi}}$ & $21.4^{\text {def }}$ & $2.5^{\mathrm{gj}}$ \\
\hline Glomus mosseae No. 2 & $7.3^{\mathrm{fi}}$ & $3.3^{\mathrm{dh}}$ & $11.5^{\text {eh }}$ & $22.1^{\text {def }}$ & $2.7^{\text {ghi }}$ \\
\hline Glomus microcarpus No. 1 & $7.5^{\mathrm{fi}}$ & $4.3^{b f}$ & $11.5^{\text {eh }}$ & $21.6^{\mathrm{def}}$ & $2.5^{\mathrm{g} j}$ \\
\hline Glomus caledonius no. 1 & $7.6^{\text {eh }}$ & $4.0^{\mathrm{bg}}$ & $10.6^{\mathrm{fj}}$ & $21.8^{\text {def }}$ & $2.7^{\text {ghi }}$ \\
\hline Glomus etunicatus & $7.8^{\mathrm{eh}}$ & $3.2^{\text {eh }}$ & $11.8^{\mathrm{dh}}$ & $23.0^{\mathrm{de}}$ & $2.9^{\mathrm{ch}}$ \\
\hline Glomus mosseae No. 1 & $8.3^{\mathrm{dg}}$ & $4.8^{\text {bcd }}$ & $13.0^{\mathrm{bf}}$ & $24.6^{\text {cde }}$ & $3.1^{\mathrm{cg}}$ \\
\hline \multicolumn{6}{|c|}{ High fertility } \\
\hline Glomus microcarpus No. 5 & $7.3^{\mathrm{fi}}$ & $5.5^{\mathrm{ab}}$ & $11.1^{\mathrm{fi}}$ & $20.6^{\text {efg }}$ & $2.7^{\text {ghi }}$ \\
\hline Control (non-mycorrhizal) & $7.5^{\mathrm{fi}}$ & $3.9^{\mathrm{bg}}$ & $10.8^{\mathrm{fj}}$ & $21.3^{\mathrm{def}}$ & $2.6^{\mathrm{gj}}$ \\
\hline Glomus microcarpus No. 4 & $8.1^{\mathrm{dg}}$ & $4.4^{\mathrm{bf}}$ & $12.4^{\mathrm{cg}}$ & $22.9^{\text {de }}$ & $3.1^{\mathrm{cg}}$ \\
\hline Glomus fasciculatus N. 2 & $8.9^{\mathrm{eg}}$ & $4.5^{b f}$ & $12.5^{\mathrm{cg}}$ & $24.6^{\text {cde }}$ & $3.2^{\mathrm{cg}}$ \\
\hline Glomus microcarpus No. 2 & $9.1^{\text {bf }}$ & $3.7^{\mathrm{ch}}$ & $14.6^{\mathrm{ae}}$ & $26.8^{\text {bcd }}$ & $3.5^{b f}$ \\
\hline Glomus microcarpus No. 3 & $9.3^{\text {be }}$ & $5.1^{b c}$ & $15.0^{a b c}$ & $29.6^{a b c}$ & $3.8^{\text {ad }}$ \\
\hline Glomus mosseae No. 2 & $9.6^{\mathrm{bcd}}$ & $4.4^{\mathrm{bf}}$ & $16.0^{\mathrm{ab}}$ & $31.6^{\mathrm{ab}}$ & $3.9^{a b c}$ \\
\hline Glomus etunicafus & $9.8^{\mathrm{bcd}}$ & $4.6^{\text {be }}$ & $15.9^{\mathrm{ab}}$ & $30.0^{a b c}$ & $3.9^{a b c}$ \\
\hline Glomus caledonius no. 1 & $9.9^{\text {bcd }}$ & $3.8^{\mathrm{cg}}$ & $14.6^{\mathrm{ae}}$ & $29.9^{a b c}$ & $3.6^{b c}$ \\
\hline Glomus caledonius no. 2 & $10.2^{b c}$ & $3.1^{\text {eh }}$ & $14.9^{\mathrm{ad}}$ & $30.3^{a b c}$ & $4.0^{\mathrm{ab}}$ \\
\hline Glomus microcarpus No. 1 & $10.7^{\mathrm{ab}}$ & $4.7^{\text {be }}$ & $16.9^{\mathrm{a}}$ & $34.5^{\mathrm{a}}$ & $4.4^{\mathrm{a}}$ \\
\hline Glomus fasciculatus N. 1 & $10.8^{\mathrm{ab}}$ & $5.0^{\mathrm{bc}}$ & $16.6^{\mathrm{a}}$ & $32.8^{\mathrm{a}}$ & $4.1^{\mathrm{ab}}$ \\
\hline Glomus mosseae No. 1 & $12.3^{\mathrm{a}}$ & $6.5^{\mathrm{a}}$ & $17.4^{\mathrm{a}}$ & $34.4^{\mathrm{a}}$ & $4.4^{\mathrm{a}}$ \\
\hline
\end{tabular}

$\dagger \quad$ Treatments were first separated into high and low fertility groups, then arranged in an order corresponding to their decreasing top dry weight.

All other parameters are arranged in the same order, regardless of their values.

$\$$ Each value is the mean of 8 replicates.

Number in each column followed by the same letter are not significantly different at the $5 \%$ level, according to Duncan's Multiple Range Test. 
In addition, to the interspecific differences described above, intraspecific differences also appeared in some cases. Although the two isolates of $\mathrm{G}$. caledonius were not significantly different from each other in either the high or low fertility soil, the two isolates of $\mathrm{G}$. fasciculatus were significantly different from each other in both soils. G. mosseae no. 1 was significantly different from G. mosseae no. 2 in the high fertility soil but not in the low fertility soil. Similarly, the five isolates of G. microcarpus fall into two statistical categories in the high fertility soil, but were all the same under low fertility conditions.
It appears from these data that as much variation, with respect to an isolate's ability to stimulate growth and yield of soybeans, can be observed within a species as between species.

\section{Experiment 2}

Of the seven isolates tested in the experiment, only two (Glomus epigaeus and Gigaspora corraloidea) stimulated soybean growth and yield (Table 4). Both isolates produced significant increases in the high and low fertility soils, and, as in experiment 1 , the growth responses were generally greater in the low fertility soil.

Table 4. Growth and yield response of soybean to colonization by the experiment 2 fungi in a high or low fertility soil

\begin{tabular}{|c|c|c|c|c|c|c|c|}
\hline \multirow{2}{*}{ Fungus } & \multicolumn{2}{|c|}{ Treatment } & \multirow{2}{*}{$\begin{array}{l}\text { Top dry } \\
\text { weight }\end{array}$} & \multirow{2}{*}{$\begin{array}{l}\text { Root dry } \\
\text { weight }\end{array}$} & \multirow{2}{*}{$\begin{array}{c}\text { No. } \\
\text { pods }\end{array}$} & \multirow{2}{*}{ Seeds ${ }^{*}$} & \multirow{2}{*}{$\begin{array}{l}\text { Seed dry } \\
\text { weight }\end{array}$} \\
\hline & Fertility & $\mathbf{M}$ or $\mathbf{N}^{\dagger}$ & & & & & \\
\hline \multirow{4}{*}{ Gigaspora margarita no. 1} & $\mathrm{H}$ & $\mathrm{M}$ & $6.2^{\mathrm{ab}}$ & $4.0^{\mathrm{a}}$ & $9^{\mathrm{ab}}$ & $19^{\mathrm{ab}}$ & $2.5^{\mathrm{ab}}$ \\
\hline & $\mathrm{H}$ & $\mathrm{N}$ & $7.3^{\mathrm{a}}$ & $3.3^{\mathrm{a}}$ & $11^{\mathrm{a}}$ & $24^{\mathrm{a}}$ & $3.0^{\mathrm{a}}$ \\
\hline & $\mathrm{L}$ & M & $4.8^{b}$ & $3.2^{\mathrm{a}}$ & $7^{\mathrm{bc}}$ & $14^{\mathrm{bc}}$ & $1.7^{b c}$ \\
\hline & $\mathrm{L}$ & $\mathrm{N}$ & $3.3^{b}$ & $2.6^{\mathrm{a}}$ & $5^{c}$ & $9^{c}$ & $1.2^{\mathrm{c}}$ \\
\hline \multirow{4}{*}{ Gigaspora margarita no. 2} & $\mathrm{H}$ & $\mathrm{M}$ & $8.2^{\mathrm{a}}$ & $2.8^{a b}$ & $12^{\mathrm{ab}}$ & $23^{b}$ & $3.0^{\mathrm{a}}$ \\
\hline & $\mathrm{H}$ & $\mathrm{N}$ & $9.0^{\mathrm{a}}$ & $4.0^{\mathrm{a}}$ & $13^{\mathrm{a}}$ & $31^{\mathrm{a}}$ & $3.9^{\mathrm{ab}}$ \\
\hline & $\mathrm{L}$ & M & $4.6^{\mathrm{b}}$ & $1.8^{\mathrm{b}}$ & $8^{c}$ & $14^{\mathrm{c}}$ & $1.7^{\mathrm{c}}$ \\
\hline & $\mathrm{L}$ & $\mathrm{N}$ & $5.5^{b}$ & $3.8^{\mathrm{a}}$ & $9^{b c}$ & $17^{\mathrm{bc}}$ & $2.1^{b c}$ \\
\hline \multirow{4}{*}{ Gigaspora margarita no. 3} & $\mathrm{H}$ & $\mathrm{M}$ & $7.4^{\mathrm{a}}$ & $2.7^{\mathrm{ab}}$ & $12^{\mathrm{a}}$ & $24^{\mathrm{a}}$ & $3.2^{\mathrm{a}}$ \\
\hline & $\mathrm{H}$ & $\mathrm{N}$ & $7.5^{\mathrm{a}}$ & $3.4^{\mathrm{a}}$ & $14^{\mathrm{a}}$ & $26^{\mathrm{a}}$ & $3.2^{\mathrm{a}}$ \\
\hline & $\mathrm{L}$ & M & $2.9^{\mathrm{b}}$ & $1.9^{b}$ & $5^{b}$ & $10^{b}$ & $1.1^{\mathrm{b}}$ \\
\hline & $\mathrm{L}$ & $\mathrm{N}$ & $4.4^{\mathrm{b}}$ & $3.7^{\mathrm{a}}$ & $7^{b}$ & $13 \mathrm{~b}$ & $1.5^{\mathrm{b}}$ \\
\hline \multirow{4}{*}{ Gigaspora margarita no. 4} & $\mathrm{H}$ & $\mathrm{M}$ & $7.0^{\mathrm{a}}$ & $2.6^{\mathrm{ab}}$ & $21^{a}$ & $22^{\mathrm{a}}$ & $2.9^{\mathrm{a}}$ \\
\hline & $\mathrm{H}$ & $\mathrm{N}$ & $6.8^{\mathrm{a}}$ & $3.7^{\mathrm{a}}$ & $13^{\mathrm{a}}$ & $24^{\mathrm{a}}$ & $3.1^{\mathrm{a}}$ \\
\hline & $\mathrm{L}$ & M & $2.9^{b}$ & $1.7^{\mathrm{b}}$ & $5^{b}$ & $7^{b}$ & $0.9^{\mathrm{b}}$ \\
\hline & $\mathrm{L}$ & $\mathrm{N}$ & $3.4^{\mathrm{b}}$ & $3.4^{\mathrm{a}}$ & $6^{b}$ & $9^{b}$ & $1.1^{\mathrm{b}}$ \\
\hline \multirow{4}{*}{ Gigaspora gigantean } & $\mathrm{H}$ & $\mathrm{M}$ & $6.4^{\mathrm{a}}$ & $2.6^{\mathrm{ab}}$ & $11^{\mathrm{a}}$ & $22^{\mathrm{a}}$ & $2.8^{\mathrm{a}}$ \\
\hline & $\mathrm{H}$ & $\mathrm{N}$ & $6.8^{\mathrm{a}}$ & $3.7^{\mathrm{a}}$ & $13^{\mathrm{a}}$ & $24^{\mathrm{a}}$ & $3.1^{\mathrm{a}}$ \\
\hline & $\mathrm{L}$ & M & $2.7^{\mathrm{b}}$ & $1.7^{\mathrm{b}}$ & $4^{b}$ & $8^{b}$ & $0.8^{\mathrm{b}}$ \\
\hline & $\mathrm{L}$ & $\mathrm{N}$ & $3.4^{\mathrm{b}}$ & $3.4^{\mathrm{a}}$ & $6^{b}$ & $9^{b}$ & $1.1^{\mathrm{b}}$ \\
\hline \multirow{4}{*}{ Gigaspora coralloidea } & $\mathrm{H}$ & M & $8.5^{\mathrm{a}}$ & $3.0^{\mathrm{a}}$ & $15^{\mathrm{a}}$ & $30^{\mathrm{a}}$ & $4.0^{\mathrm{a}}$ \\
\hline & $\mathrm{H}$ & $\mathrm{N}$ & $6.1^{\mathrm{b}}$ & $2.9^{\mathrm{ab}}$ & $12^{\mathrm{a}}$ & $22^{b}$ & $3.0^{\mathrm{b}}$ \\
\hline & $\mathrm{L}$ & M & $5.5^{b}$ & $1.7^{\mathrm{b}}$ & $8^{b}$ & $18^{\mathrm{b}}$ & $2.1^{\mathrm{b}}$ \\
\hline & $\mathrm{L}$ & $\mathrm{N}$ & $2.9 \mathrm{c}$ & $2.3^{b}$ & $4^{b}$ & $8^{c}$ & $1.1^{\mathrm{c}}$ \\
\hline \multirow{4}{*}{ Glomus epigaeus } & $\mathrm{H}$ & $\mathrm{M}$ & $10.2^{\mathrm{a}}$ & $2.6^{\mathrm{a}}$ & $18^{\mathrm{a}}$ & $35^{\mathrm{a}}$ & $4.1^{\mathrm{a}}$ \\
\hline & $\mathrm{H}$ & $\mathrm{N}$ & $7.1^{b}$ & $2.0^{\mathrm{a}}$ & $11^{\mathrm{b}}$ & $23^{c}$ & $2.7^{\mathrm{b}}$ \\
\hline & $\mathrm{L}$ & M & $9.9^{\mathrm{a}}$ & $2.5^{\mathrm{a}}$ & $15^{b}$ & $28^{\mathrm{b}}$ & $2.8^{b}$ \\
\hline & $\mathrm{L}$ & $\mathrm{N}$ & $3.3^{\mathrm{c}}$ & $2.4^{\mathrm{a}}$ & $5^{c}$ & $9^{d}$ & $1.1^{\mathrm{c}}$ \\
\hline
\end{tabular}

$\dagger \mathrm{M}=$ mycorrhizal, $\mathrm{N}=$ non-mycorrhizal.

Each value is the mean of 3 replicates. The 4 values in each column following each fungus that are followed by the same letter are not significantly different at the 5\% level, according to Duncan's Multiple Range Test. As explained in the text, inter-isolate comparisons were not made on the experiment 2 fungi. 
Growth and yield increases due to colonization by G. epigaeus were of a similar magnitude to those increases induced by G. mosseae no. 1 in experiment 1 .

No positive increases in growth and yield were observed in response to colonization by the other five experiment 2 isolates (Gigaspora margarita no. 1, 2, 3, 4 and Gigaspora gigantea). When differences did appear between mycorrhizal and non-mycorrhizal treatments (Table 4), there was an indication of a growth decrease, rather than the expected increase, suggesting these five isolates may have a suppressive effect on soybean growth and yield.

Before attempting to make a comparative evaluation of growth responses to a plant, soybean in this instance, to colonization by one of several species or isolates of VA mycorrhizal fungi, it was first necessary to resolve the question of inoculum uniformity. What would be the best inoculation procedure; a practical procedure that would assure a uniform exposure to each fungi isolate?

The simplest and most logical approach appeared to be inoculation with spores only, and standardization of spore quantities among isolates. Although the "spores only" inoculation procedure offered an easy means of quantification and an ostensibly accurate means of standardization, there were limitations. First of all, in order for a "spores only" inoculation procedure to be truly uniform among isolates, it would be necessary to assume that a spore of one isolate was equivalent (in terms of its capacity to colonize host roots) to a spore of each of the other isolates considering the tremendous variability in spore size (from $<25$ to $>500 \mu \mathrm{m}$ ) among the isolates tested, did not believe it would be correct to make this assumption. Other difficulties which also limited the practical usefulness of a "spores only" inoculation procedure included variation in the percent of spore germination among isolates, the inability of a "spores only" inoculum (of some isolates) to produce consistent infections from one experiment to the next, and the problems of producing the copious quantities of spores (not all species and isolates prone to produce spores in great numbers) necessary for inoculation of large scale experiments. After considering these factors, it seemed clear that the use of "spores only" inoculum offered no practical advantage.

An alternative to inoculation with spores only was inoculation with a pot culture produced mixture containing fungal structures (spores, intra- and extraroot vesicles, mycelium) colonized root fragments, and soil. Preliminary studies in laboratory confirmed this method of inoculatioin to be a very consistent and effective means of establishing mycorrhizae on soybean under the greenhouse conditions descried. Mycorrhizal synthesis was maximized by saturating the system with a quantity of mixed inoculum well in excess of that required to produce the highest levels of colonization (Carling et al., 1979; Komang and Ralebits ., 2016). Although the problem of interisolate standardization of inoculum was not eliminated by the use of this inoculation procedure, believing that by saturating each system with inoculum, and thus maximizing mycorrhizal synthesis, having minimized the influence that differences in inoculum density would have on the measurement of effectivity.

In a discussion of specificity in AV mycorrhizae, Mosse (1974) and EL-Sayed (2002) stated some isolates of VA mycorrhizal fungi are more effective than others; effectivity being defined as "the degree of nutritional or other advantage resulting from the symbiotic association between a particular autotroph and heterotroph". Indeed, interspecific differences in effectivity have been clearly demonstrated by many investigators using a variety of host plants (Hall, 1976; Mosse, 1972 a and b); Powell, 1975; Sanders et al., 1977). The data demonstrate that effectivity differences also appear with soybean at a host, not only among species of AV mycorrhizal fungi (interspecific), but also among different isolates of the same species (intraspecific).

The statistical relationships of intraspecific isolates are based on growth response data and thus reflect effectivity, with isolates in the same statistical category possessing the same effectivity. The relationship between isolates of G. mosseae or among isolates of G. microcarpus changed with fluctuations in soil fertility. However, relationships between intraspecific isolates of G. caledonius or G. fasciculatus were not influenced by soil fertility. The biological significance of effectivity difference, and changes in effectivity between intraspecific isolates induced by differences in soil fertility, is not clear at this time and will require further study. However, it does appear that intraspecific effectivity can be great, possibly as great as interspecific effectivity differences. It also appears that relative effectivity is independent of soil fertility.

The performance of a majority of the experiment 1 isolates, in high fertility soil, was in contrast to the widely held view that endomycorrhizae can be a significant factor only in infertile soils. The quantity of available $\mathrm{P}$ in the high fertility soil was expected to depress the effectivity of the tested isolates. In some cases this was true, but in other cases (most noteably G. caledonius no. 2) the biomass increase in TDW and SDW over the non-mycorrhizal control was greater in the high fertility soil. Hayman et al. (1976) and 
Gerdemann (1970) have stated that certain crops may be heavily mycorrhizal even in very fertile soils. Observation high levels of mycorrhizal infection in the roots of soybeans grown in fertile field soils. These observations indicate that some isolates of $\mathrm{AV}$ mycorrhizal fungi may be adapted to high fertility soils, and the possibility exists that some isolates may be effective only under high fertility conditions. Future selection and seting of AV mycorrhizal fungi should, believing, take this possibility into account.

The some VA mycorrhizal fungi may be responsible for suppression of growth and reduction of yield is suggested in experiment 2 data. This possibility of reduced growth in response to colonization by mycorrhizal fungi is not a new concept, however, as negative (Laycock, 1945; Meloh, 1963 ; EL- Sayed ,2003) or neutral (Hayman and Mosse, 1971; Deveau et al ., 2016) responses to colonization have been reported. Additional citation on this subject, describing VA mycorrhizal fungi as possible plant pathogens, have been summarized by Schenck and Kellam (1978) and EL-Sayed (2015). The result obtained was not entirely unexpected, however, as preliminary experiments with G. margarita no. 3 had indicated little or no increase in growth and yield. At the same time, the data not expect to see each of the G. margarita isolates perform in a similar manner. The additional study is required on the potential negative aspects to mycorrhizal infection before any firm conclusions can be drawn, but in the meantime, all mycorrhizal investigators should be aware of the possibility.

\section{CONCLUSIONS}

The experiments reported here were conducted under greenhouse conditions. When interpreting these data, or data that other have complied in similar comparative effectivity tests of VA mycorrhizal fungi, it is important to remember that the circumstances of plant culture vary, not only from crop to crop, but from location to location as well. Therefore, data must expect the relative effectivity of isolates to vary as the host and physical conditions change. Soil texture, available nutrients, $\mathrm{pH}$, temperature, moisture, host plant, and other factors all may play a role in determining effectivity of a particular isolate. As a result, a mycorrhizal fungus that performs well with one host plant under a particular set of environmental conditions may not do well with another host under the same conditions or the same host under different conditions. The data, therefore, can be cited neither as an indication of species and isolates that will increase soybean growth and yield in the field, nor can they be used to predict which of these species and isolates will be effective on other host plants. Each system appears to be unique, and each must be evaluated experimentally before the question pertaining to effectivity of a specific AV mycorrhizal fungus in that system can be answered.

The demonstration of increased growth by soybean (and other plants) in response to colonization by selected isolates of VA mycorrhizal fungi under greenhouse conditions has become routine. Effectivity differences among isolates of $\mathrm{AV}$ mycorrhizal fungi colonizing greenhouse grown plants has also bee confirmed. The challenge now will be to convincingly demonstrate that these principles also function in the field.

\section{ACKNOWLEDGMENTS}

The author wish to acknowledge grateful and special thanks to the Eng. Mohammed Said Abbas for valuable practically supported to this research for providing inoculum.

\section{REFERENCES}

Becker, W.N. and I.R. Hall. 1976. Bigaspora margarita, a new species in the Endogonaceae, Mycotaxon 4: 155-160.

Becker, W.N., and J.W. Gerdemann. 1977. Glomus etunicatus sp. nov. Mycotaxon. 6 (1): 29-32.

Carling, D.E.; M.F. Brown, and R.A. Brown. 1979. Colonization rates and growth responses of soybean plants infected by vesicular-arbuscular mycorrhizal fungi. Can. J. Bot. 57: 1769-1772.

Daniels, B.A., and J.M. Trappe. 1979. Glomus epigaeus sp. nov., a useful fungus for vesicular-arbuscular mycorrhizal research. Can. J. Bot. 57: 539-542.

Deveau,A.,Antony-Babu,S.,LeTacon,F.,Robin,C.,Frey-Klett, P., ndUroz, S. 2016. Temporal changes of bacterial communities in tuber melanosporum ectomycorrhizosphere during ascocarp development.Mycorrhiza .(in press).

EL-Sayed, S.A.M. 2002. Relationship between mycorrhizae and uptake of some elements in corn and guar.Assiut Univ. Bull.Environ. Res.5(2):17-28 .

EL-Sayed,S.A.M.2003.Effect of EDDHA amendment to soil on P solubility and availability by mycorrhizal guar plant. Alex. Sci. Exch. 24(1):1- 18.

EL-Sayed, S. A. M. 2015 .Ammonium polyphosphate and ammonium orthophosphate as sources of phosphorus for Jerusalem artichoke. Alex. Sci. Exch. Jour. 36 (1): 47 57.

Gerdemann, J.W. 1968. Vesicular-arbuscular mycorrhiza and plant growth. AEnn. Rev. Phytopathol. 6: 397-418.

Gerdemann, J.W. 1970. The significance of vesiculararbuscular mycorrhizae in plant nutrition. P. 125-129. In T.A. Toussoun, R.V. Bega, and P.S. Nelson (ed.). Root diseases and soil-borne plant pathogens. Univ. of Calif. Press, Berkeley, Calif. 
Gerdemann, J.W. and J.M. Trappe. 1974. The Endogonaceae in the pacific Northwest, Mycologi Memoir (New York Botanical Gardens), 5: 1-76.

Hall, I.R. 1976. Responses of coprosma robusta to different forms endomycorrhizal inoculum. Trans. Br. Mycol. Soc. 67: 409-411.

Hayman, D.S., and B. Mosse. 1971. Plant growth responses to vesicular-arbuscular mycorrhiza. 1- Growth of Endogone inoculated plants in phosphate deficient soils. New Phytol. 70: 9-27.

Hayman, D.S.; J.M. Barea, and R. Azcon. 1976. Vesiculararbuscular mycorrhiza in southern Spain: its distribution in crops growing in soil of different fertility. Phytopathol. Mediterr. Vol. XV (1): 1-6.

Komang,T.; O, Ralebits. 2016. Essential Soil Microbial Ecology . Agron . J.100(1) :178-181 .

Laycock, D.H. 1945. Preliminary investigations into the function of the endotrophic mycrorrhiza of Theobroma cacao L. Trop. Agric. 22: 77-80.

Meloh, K.A. 1963. Untersuchungen Zur biologie der endotrophen mycorrhiza bei Zea mays L. and Avena sativa L. Arch. Mikrobiol. 46: 369-381.

Mosse, B. 1972a. The effect of diff. endogone strains on the growth of paspalum notatum. Nature, 239: 221-223.

Mosse, B. 1972b. The influence of soil type and endogone strain on the growth of mycorrhizal plants in phosphate deficient soils. Rev. Ecol. Biol. Sol. 9: 529-537.
Mosse, B. 1973. Advances in the study of vesicular-arbuscular mycorrhiza. Ann. Rev. Phytopathol. 11: 171-196.

Mosse, B. 1974. Specificity in mycorrhizas. P. 469-484. In: F.E. Sanders, B. Mosse, and P. Tinker (ed.) Endomycorrhizas. Academic Press, London.

Powell, C.L.I. 1975. Plant growth responses to vesiculararbuscular mycorrhiza. VIII. Uptake of phosphorus by onion and clover infected with different Endogone spore types in ${ }^{32}$ P-labelled soils. New Phytol. 75: 563-566.

Ross, J.P. 1971. Effect of phosphate fertilization on yield of mycorrhizal and non-mycorrhizal soybeans. Phytopathology. 61: 1400-1403.

Ross, J.P., and J.A. Harper. 1970. Effect of Endogone mycorrhiza on soybean yields. Phytopathology. 60: 15521556.

Sanders, F.E.; P. Tinker, R.L. Black, and S.M. Palmerley. 1977. The development of endomycorrhizal root systems. I- Spread of infection and growth promoting effects with four species of vesicular-arbuscular endophyte. New Phytol. 78: 257-268.

Schenck, N.C. and M.K. Kellam. 1978. The influence of vesicular-arbuscular mycorrhizae on disease development. Univ. of Fla. Tech. Bull. No. 798.

Schenck, N.C., and K. Hinson. 1973. Response of nodulating and non-nodulating soybean to a species of Endogone mycorrhiza. Agron. J. 65: 849-850. 


\section{المالخص المري}

\section{حصر الفاربك الميكورهيزافي مزرعة كلية الزراعة - جامعة الأزهر بمحانلة أسيوا}

سعيد عبلس محمد اللسيد

الميكورهيزا vesicular-arbuscular وكل عزلة يم ققييمه L

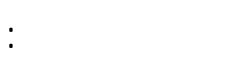

$$
\text { في حالتين: }
$$

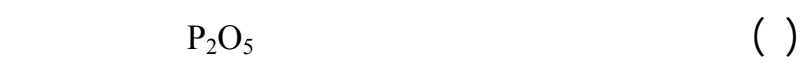

$$
\text { كجم/ فدلن. }
$$

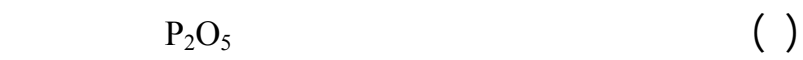

$$
\text { كجه / فدان. }
$$

أوضحت النتائج أن مغم العزلات كانت معنوية وأدت

ا و فطريت جذرية من جنس Glomus SP

r. فظريك جذرية من جنس GigasporaSP

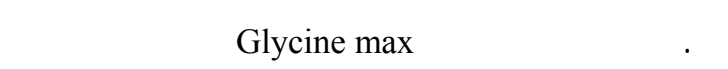
ع. فظريك جذرية من نوع الميكروهيزا Vesicular-arbuscular(VA)mycorrhizal fungi

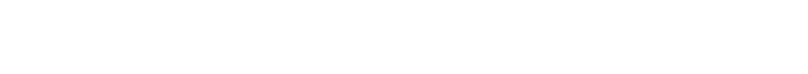

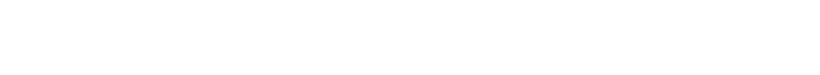

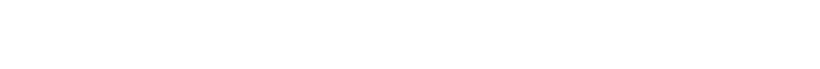

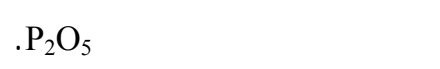

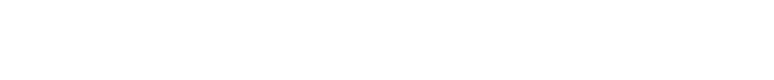

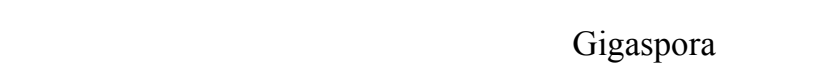
للقمم النلمية وكذلك محصول الحبوب للك من تسميد التربة وهل انواع دلخلية Endotrophic حيث ينمو الفطر بحيث تكون الهيفا بينطقة البثرة وطقة الفثرة حي ـث تك -وّن

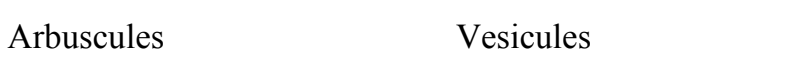
لتبالل المغنيت بين الفطر والنبت العالأ.

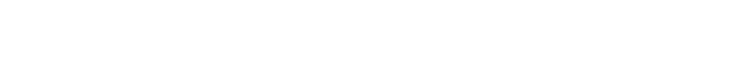
جيزه rم للنمو في صوب زجلجية حيث مق عزل عدل عدد 19

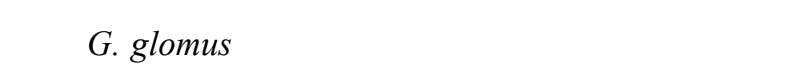

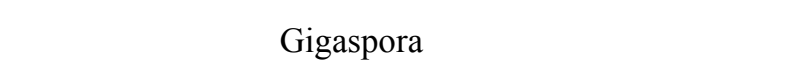

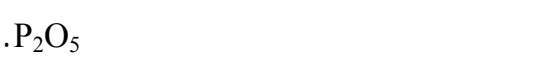

